Article

\title{
Governing Constraints of Chromium(VI) Formation from Chromium(III)-Bearing Minerals in Soils and Sediments
}

\author{
Debra Hausladen ${ }^{1,2, * \mathbb{D}}$, Sarah Fakhreddine ${ }^{1}$ and Scott Fendorf ${ }^{1}$ \\ 1 Earth System Science Department, Stanford University, Stanford, CA 94305, USA; \\ sarahfak@alumni.stanford.edu (S.F.); fendorf@stanford.edu (S.F.) \\ 2 Civil and Environmental Engineering Department, Université de Sherbrooke, Sherbrooke, QC J1K 2R1, \\ Canada \\ * Correspondence: debra.hausladen@usherbrooke.ca; Tel.: +1-819-821-8000 (ext. 62507)
}

Received: 3 October 2019; Accepted: 7 November 2019; Published: 13 November 2019

\begin{abstract}
The potential for geogenic $\mathrm{Cr}(\mathrm{VI})$ contamination is vast, yet it is difficult to predict susceptible environments as groundwater $\mathrm{Cr}(\mathrm{VI})$ concentrations vary significantly, even within a given aquifer, due to physical and hydrologic heterogeneity. The physical structure of soils and sediments exerts a dominant control on $\mathrm{Cr}(\mathrm{VI})$ production by dictating the separation distance of reactive phases, the diffusion distance from $\mathrm{Cr}(\mathrm{VI})$ generation sites to advecting groundwater, and by influencing infiltration rates and porewater velocity. Here, we used a dual-pore domain model to investigate the relative control of these parameters on $\mathrm{Cr}(\mathrm{VI})$ production. The reaction distance between $\mathrm{Cr}(\mathrm{III})$-bearing minerals and $\mathrm{Mn}$ oxides predominantly controls $\mathrm{Cr}(\mathrm{VI})$ export to advecting groundwater, while changes in diffusion distance between sites of $\mathrm{Cr}(\mathrm{VI})$ generation and advective flow channels generally have little impact on steady-state $\mathrm{Cr}(\mathrm{VI})$ concentrations. Changes in $\mathrm{Cr}(\mathrm{VI})$ diffusion distance can, however, increase the time required for groundwater $\mathrm{Cr}(\mathrm{VI})$ concentrations to reach a steady-state; thus, under fluctuating hydrologic and biogeochemical conditions, long diffusion distances still have the potential to suppress $\mathrm{Cr}(\mathrm{VI})$ supply to advecting water. Furthermore, we show that high porewater flow velocities effectively dilute $\mathrm{Cr}(\mathrm{VI})$ diffusing from soil/sediment aggregates, thus minimizing $\mathrm{Cr}(\mathrm{VI})$ concentrations relative to lower porewater velocities. The strong control that the physical/hydrologic parameters exert on $\mathrm{Cr}(\mathrm{VI})$ production appears to overwhelm the impact of $\mathrm{Cr}(\mathrm{III})$-mineral solubility within soils and sediments.
\end{abstract}

Keywords: indigenous contaminants; Mn oxides; reactive transport modeling; dual domain model

\section{Introduction}

Hexavalent chromium concentrations exceeding recommended drinking water limits have increasingly been found in aquifers devoid of industrial or other anthropogenic sources [1-9]. In fact, naturally-occurring $\mathrm{Cr}(\mathrm{VI})$ groundwater concentrations of over $60 \mu \mathrm{g} \mathrm{L} \mathrm{L}^{-1}$ have been reported $[1,3,4,6]$. Given the wide-distribution of $\mathrm{Cr}(\mathrm{III})$-bearing mineral phases that reside in ultramafic igneous rocks such as peridotites and dunites, their metamorphic derivatives such as serpentinites, and associated soils $[10,11]$, the growing prevalence of $\mathrm{Cr}(\mathrm{VI})$ generated from geogenic sources is of concern, predominantly in regions throughout the circum-Pacific and Mediterranean regions $[10,11]$.

In these ultramafic igneous rocks and their metamorphic derivatives, primarily found along convergent margins, $\mathrm{Cr}$ resides in low solubility minerals (e.g., chromite, Cr-silicates, and Cr-magnetite) [11,12]. Chromium, along with $\mathrm{Fe}$ and $\mathrm{Mn}$, are preferentially concentrated and repartitioned during weathering [13-15], with Cr(III) concentrations ranging from $200 \mathrm{mg} \mathrm{kg}^{-1}$ up to $6 \mathrm{wt.} \%$ in soils in more highly weathered, tropical regions [10]. While Cr(III) remains in low 
solubility primary minerals, especially in temperate climates, secondary alteration minerals (including aluminosilicate clays, $\mathrm{Cr} / \mathrm{Fe}$ (hydr)oxides, and various phosphates) concentrate along advective flow channels that transect saprolite and soil $[13,16,17]$. Similarly, $\mathrm{Mn}$ is released from ultramafic rocks where it is hosted in primary minerals such as olivine, pyroxene, and garnet. As divalent manganese $\left(\mathrm{Mn}^{2+}\right)$ is the most stable oxidation state for Mn during magmatic processes, Mn readily substitutes for $\mathrm{Fe}^{2+}$ and $\mathrm{Mg}^{2+}$ in minerals due to the comparable ionic radius of $\mathrm{Mn}^{2+}$ [18]. Manganese is therefore partitioned into ferromagnesian silicates and Fe-Ti oxides, becoming enriched in these $\mathrm{Cr}$-rich ultramafic igneous rocks. During weathering, this Mn may then be repartitioned as Mn(III/IV) oxides along advective flow channels [13].

The wide-distribution of $\mathrm{Cr}(\mathrm{III})$-bearing minerals has the potential to result in similarly distributed $\mathrm{Cr}(\mathrm{VI})$ contamination of groundwater. Spatial variation in dissolved $\mathrm{Cr}(\mathrm{VI})$ concentrations is extensive, however, and a simple link between solid-phase $\mathrm{Cr}(\mathrm{III})$ concentrations in parent rock or weathering products and aqueous $\mathrm{Cr}(\mathrm{VI})$ concentrations is absent. Rather, groundwater $\mathrm{Cr}(\mathrm{VI})$ concentrations likely depend on a complex interplay of the $\mathrm{Cr}(\mathrm{III})$ host phase(s), distribution of $\mathrm{Mn}(\mathrm{III} / \mathrm{IV})$ oxides, soil/sediment structure, and hydrology.

Generation of $\mathrm{Cr}(\mathrm{VI})$ from geogenic $\mathrm{Cr}(\mathrm{III})$ sources is generally dependent on the reaction of two solids of limited solubility: $\mathrm{Cr}(\mathrm{III})$ - and $\mathrm{Mn}(\mathrm{III} / \mathrm{IV})$-bearing minerals. Soils and sediments have a complex flow network that is composed of small pores (micropores) where diffusion dominates, and may intersect large pores (macropores) where advection dominates. Given that soils and sediments essentially have fixed structures over short time-periods, the distance between these two low solubility phases is likely to have a central control on $\mathrm{Cr}(\mathrm{VI})$ production. Although both $\mathrm{Cr}(\mathrm{III})$-bearing minerals and $\mathrm{Mn}(\mathrm{III} / \mathrm{IV})$ oxides have limited solubilities, the rate of $\mathrm{Cr}(\mathrm{VI})$ generation depends on dissolved $\mathrm{Cr}(\mathrm{III})$ concentrations $[11,19,20]$. Thus, the solubility of the $\mathrm{Cr}(\mathrm{III})$-bearing mineral phases may additionally influence diffusion gradients and thereby the subsequent reaction rates with $\mathrm{Mn}$ oxide. Mills et al. [21], for example, posited that decreases in soil $\mathrm{pH}$ resulted in increased $\mathrm{Cr}$ (III) desorption from cation exchange sites and enhanced $\mathrm{Cr}(\mathrm{VI})$ production. Furthermore, if $\mathrm{Cr}(\mathrm{VI})$ is generated within a micropore, the distance between the location of generation and advecting porewater may influence groundwater concentrations. Additionally, the rate of $\mathrm{Cr}(\mathrm{VI})$ diffusive flux into macropores relative to the volume of advecting water will influence groundwater $\mathrm{Cr}(\mathrm{VI})$ concentrations. Indeed, groundwater recharge has been linked with variation in aqueous $\mathrm{Cr}(\mathrm{VI})$ concentrations within aquifers, where Manning et al. [22] showed that the origin and age of groundwater impacted $\mathrm{Cr}(\mathrm{VI})$ concentrations. Increases in aquifer infiltration rates effectively dilute eluting $\mathrm{Cr}(\mathrm{VI})$ and suppress aqueous $\mathrm{Cr}(\mathrm{VI})$ concentrations, while slower infiltration allows $\mathrm{Cr}(\mathrm{VI})$ within diffusive domains to equilibrate more extensively with advecting water.

Ultimately, as depicted in Figure 1, Cr(VI) groundwater concentrations are constrained by (1) $\mathrm{Cr}$ (III) dissolution rates; (2) the reactive distance between $\mathrm{Cr}$ and Mn oxides; (3) the solubility of $\mathrm{Cr}$ (III)-bearing mineral phases; (4) the diffusive distance of the generation sites to advective flow channels; and (5) the porewater velocity of infiltrating groundwater. The contribution of each factor/process in controlling groundwater and their coupling, however, remains elusive. Accordingly, here we develop a reactive transport model to investigate the extent to which $\mathrm{Cr}(\mathrm{VI})$ generated within soils and sediments is available for export into groundwater. We used a 1D dual domain model with three $\mathrm{Cr}$ (III)-bearing minerals of differing solubilities at various distances from reactive Mn oxide phases and advective flow channels to constrain the relative impacts of different factors on $\mathrm{Cr}(\mathrm{VI})$ transport. Our findings suggest that within the fixed structure of soils and sediments, the separation distance between $\mathrm{Cr}$ (III) and $\mathrm{Mn}(\mathrm{III} / \mathrm{IV})$ phases, together with groundwater flow velocity, primarily control $\mathrm{Cr}(\mathrm{VI})$ production. Chromium(III) mineral solubility influences oxidation rates to a minimal extent given the smaller-range of solubilities predicted for primary $\mathrm{Cr}(\mathrm{III})$ host phases. While the diffusion distance between $\mathrm{Cr}(\mathrm{VI})$ generation locales and advective flow channels has no impact on steady-state $\mathrm{Cr}(\mathrm{VI})$ concentrations, long-diffusion distances could suppress $\mathrm{Cr}(\mathrm{VI})$ concentrations in aquifers with short-term fluctuations in groundwater flow as $\mathrm{Cr}(\mathrm{VI})$ concentrations may never reach a steady-state. 


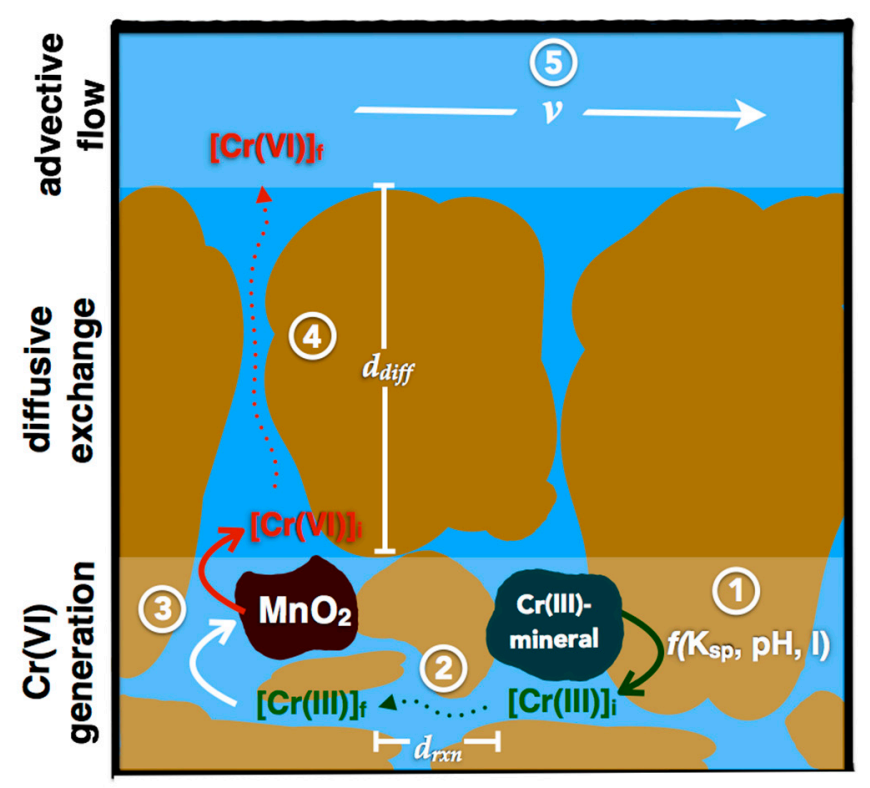

Figure 1. Conceptual model representing $\mathrm{Cr}(\mathrm{VI})$ generation within dual-pore domain soils/sediments as a function of (1) $\mathrm{Cr}(\mathrm{III})$-mineral dissolution; (2) distance between reactive phases $\left(d_{r x n}\right)$; (3) redox reaction; (4) $\mathrm{Cr}(\mathrm{VI})$ diffusion distance $\left(d_{\text {diff }}\right)$; and (5) porewater velocity $(v)$.

\section{Materials and Methods}

\subsection{Conceptual Framework}

Our conceptual model (Figure 1) represents the generation of hexavalent chromium within the aggregated structure of saturated soils/sediments and the subsequent diffusion of $\mathrm{Cr}(\mathrm{VI})$ into the surrounding porewater. Within the aggregate, a $\mathrm{Cr}(\mathrm{III})$-bearing mineral is separated from a manganese oxide mineral by a given distance $\left(d_{r x n}\right)$. Initially, there is no dissolved $\mathrm{Cr}$ in the system. As $\mathrm{Cr}(\mathrm{III})$-mineral dissolution proceeds, the dissolved $\mathrm{Cr}$ (III) concentrations reach a steady-state value controlled by the mineral solubility $\left(K_{s p}\right)$. Once aqueous $\mathrm{Cr}(\mathrm{III})$ has diffused across the separation distance to reach the $\mathrm{Mn}$ oxide surface, we assume rapid oxidation to $\mathrm{Cr}(\mathrm{VI})$. The newly generated $\mathrm{Cr}(\mathrm{VI})$ then diffuses a distance $\left(d_{\text {diff }}\right)$ to the advective porewater channel, where the water moves at a given velocity $(v)$. This model assumes the generation of $\mathrm{Cr}(\mathrm{VI})$ will continue indefinitely with no surface passivation of $\mathrm{Mn}$ oxides $\left(\mathrm{MnO}_{2}\right)$. Using these assumptions, the flux of $\mathrm{Cr}(\mathrm{III})$ to the $\mathrm{MnO}_{2}$ surface is equivalent to the flux of $\mathrm{Cr}(\mathrm{VI})$ production at the location of oxidation. This flux is calculated using Fick's first-law and depends on the solubility of the $\mathrm{Cr}(\mathrm{III})$-bearing mineral and the separation distance between the $\mathrm{Cr}(\mathrm{III})$-mineral and the $\mathrm{MnO}_{2}$. This conceptual framework was used to explore the effect of $\mathrm{Cr}(\mathrm{III})$-mineral solubility and physical heterogeneity on $\mathrm{Cr}(\mathrm{VI})$ concentrations by varying $K_{s p}, d_{r x n}, d_{d i f f}$, and $v$.

\subsection{Model Implementation}

We implemented the model using the 1D dual-domain functionality of PHREEQC [23]. The generation of $\mathrm{Cr}(\mathrm{VI})$ occurs within the immobile zone of the aggregate while the mobile zone represents the advecting porewater. The immobile and mobile zones exchange via diffusive transport. The equation describing the dual-domain system is:

$$
\frac{d C_{m}}{d t}+\frac{d C_{i m}}{d t}=D_{C r(V I)} \frac{d^{2} C_{m}}{d x^{2}}-v \frac{d C_{m}}{d x}
$$


where $C_{m}$ and $C_{i m}$ represent the molar dissolved $\mathrm{Cr}(\mathrm{VI})$ concentration in the mobile and immobile domains, respectively. $D_{C r(V I)}$ is the diffusion coefficient for $\mathrm{Cr}(\mathrm{VI})\left[\mathrm{mole} \mathrm{m}^{-2} \mathrm{~s}^{-1}\right]$ and $v\left[\mathrm{~m} \mathrm{~s}^{-1}\right]$ is the porewater velocity through the mobile domain.

The diffusive first-order exchange between mobile and immobile cells is described as:

$$
\begin{gathered}
\frac{d C_{i m}}{d t}=\alpha\left(c_{m}-c_{i m}\right)+J \\
J=-D_{o} \frac{d C}{d x} \\
\alpha=\frac{D_{C r}(V I)}{\left(a \cdot f_{s \rightarrow 1}\right)^{2}}
\end{gathered}
$$

where $C_{i m}$ is the average $\mathrm{Cr}(\mathrm{VI})$ concentration (in $\mathrm{mol} \mathrm{L}^{-1}$ ) in the immobile zone. The diffusive flux of $\mathrm{Cr}(\mathrm{VI})$ generated within the immobile domain $(J)$ depends on $\mathrm{Cr}(\mathrm{III})$-mineral solubility and separation between reactive $\mathrm{Cr}$ and $\mathrm{Mn}$ phases as described below (Equations (6) and (7)). The exchange factor $\alpha$, or mass transfer coefficient $\left(\mathrm{s}^{-1}\right)$, is related to the contact surface between the mobile and immobile domains [24]. We used a shape factor $\left(f_{s \rightarrow 1}\right)$ of 0.533 as given by Van Genuchten [24] and the PHREEQC manual [23] (Table 1, p. 53) for a plane sheet geometry of the immobile zone. The length of the immobile zone, or the effective diffusion distance $\left(d_{\text {diff }}\right)$ between the $\mathrm{Cr}(\mathrm{VI})$ generation site and the advective zone is represented as the thickness of the sheet $(2 a)$. The advective-diffusive domain is modeled with 40 mobile domain cells, each of which exchanges with one immobile domain cell of equal volume. All cells are given an identical initial solution and exchange factor, and a porosity of 1 was used for all cells to simulate saturated flow. The total length of the 1D flow domain was $1 \mathrm{~cm}$. We used $\mathrm{Cr}(\mathrm{VI})$ concentrations calculated at the last mobile cell to represent the porewater concentration of $\mathrm{Cr}(\mathrm{VI})$ transported from generation sites throughout the diffusion-controlled soil aggregates.

Table 1. Model parameter values.

\begin{tabular}{ccccc}
\hline Mineral Phases & $\mathbf{p H}$ & $\boldsymbol{d}_{\boldsymbol{r x n}}(\mathbf{m})$ & $\boldsymbol{d}_{\text {diff }}(\mathbf{m})$ & $\boldsymbol{v}\left(\mathbf{m ~ d}^{-\mathbf{1}}\right)$ \\
\hline & 5 & $10^{-10}$ & $10^{-6}$ & $10^{-2}$ \\
$\mathrm{Cr}(\mathrm{OH})_{3}(\mathrm{a})$ & 6 & $10^{-7}$ & $10^{-3}$ & $10^{-1}$ \\
$\mathrm{Cr}_{2} \mathrm{O}_{3}$ & 7.6 & $10^{-6}$ & $10^{-2}$ & $10^{0}$ \\
$\mathrm{FeCr}_{2} \mathrm{O}_{4}$ & 9 & $10^{-5}$ & $10^{-1.3}$ & \\
& & $10^{-2}$ & $10^{-1}$ & \\
\hline
\end{tabular}

In order to represent the upper limit of $\mathrm{Cr}(\mathrm{VI})$ production, a $\mathrm{Cr}(\mathrm{VI})$ flux $(\mathrm{J})$ is calculated from Fick's first law, assuming a constant flux is achieved at the reaction site, and input into the immobile cells from the following equation:

$$
\begin{gathered}
C_{i m}=J \cdot A \cdot t \\
C_{i m}=D_{C r(I I I)} \cdot \frac{\Delta C}{\Delta x} \cdot A \cdot t \\
C_{i m}=D_{C r(I I I)} \cdot \frac{C_{C r(I I I) e q}}{d_{r x n}} \cdot A \cdot t
\end{gathered}
$$

and $C_{C r(I I I) e q}$ is calculated from the solubility $\left(K_{s p}\right)$ of a range of $\operatorname{Cr}(\mathrm{III})$-bearing minerals. The concentration gradient $\Delta C$ across the reactive separation distance is approximately equivalent to $\mathrm{C}_{\mathrm{Cr}(\mathrm{III}) e q}$ as the concentration of $\mathrm{Cr}$ (III) at the $\mathrm{MnO}_{2}$ surface is assumed to be effectively depleted $\left(10^{-15} \mathrm{M}\right)$ due to the efficiency of oxidation to $\mathrm{Cr}(\mathrm{VI})$ by $\mathrm{MnO}_{2}$. The cross-sectional area of the reactive site, $\mathrm{A}\left[\mathrm{m}^{2}\right]$, is assumed to be 1 . The simulation time is represented as $t[\mathrm{~s}]$. 


\subsection{Constraining Factors of $\mathrm{Cr}(\mathrm{VI})$ Release}

Using the described dual-domain model, we examined the effect of $K_{s p}, d_{r x n}, d_{d i f f}$, and $v$ on $\mathrm{Cr}(\mathrm{VI})$ concentration in the advecting porewater. The range of values examined for each variable are listed in Tables 1 and 2.

Table 2. Solubility range of three Cr(III)-bearing minerals.

\begin{tabular}{ccc}
\hline Mineral Phase & & $\log K$ \\
\hline $\mathrm{Cr}(\mathrm{OH})_{3}(\mathrm{a})^{\mathrm{a}}$ & $\mathrm{Cr}(\mathrm{OH})_{3}+\mathrm{H}^{+}=\mathrm{Cr}(\mathrm{OH})_{2}{ }^{+}+\mathrm{H}_{2} \mathrm{O}$ & -0.49 \\
$\mathrm{Cr}_{2} \mathrm{O}_{3}{ }^{\mathrm{a}}$ & $\mathrm{Cr}_{2} \mathrm{O}_{3}+2 \mathrm{H}^{+}+\mathrm{H}_{2} \mathrm{O}=2 \mathrm{Cr}(\mathrm{OH})_{2}{ }^{+}$ & -1.32 \\
$\mathrm{FeCr}_{2} \mathrm{O}_{4}{ }^{\mathrm{b}}$ & $\mathrm{FeCr}_{2} \mathrm{O}_{4}+4 \mathrm{H}^{+}=2 \mathrm{Cr}(\mathrm{OH})_{2}{ }^{+}+\mathrm{Fe}^{2+}$ & 7.2003 \\
\hline
\end{tabular}

${ }^{a}$ Values were calculated based on Ball and Nordstrom (1998); ${ }^{b} \log K$ from Minteq v4.

\section{Results and Discussion}

Using the reactive transport model based on the processes described in Figure 1 and parameters in Tables 1 and 2, we explored the central controls on $\mathrm{Cr}(\mathrm{VI})$ generation from $\mathrm{Cr}(\mathrm{III})$ minerals. We evaluated the constraints of each of five parameters $\left(\mathrm{Cr}(\mathrm{III})\right.$ mineral solubility $\left(K_{s p}\right), \mathrm{pH}$, separation distance between reactive phases $\left(d_{r x n}\right)$, distance from $\mathrm{Cr}(\mathrm{VI})$ production sites to advective flow channels $\left(d_{d i f f}\right)$, and porewater velocity $(v))$ on $\mathrm{Cr}(\mathrm{VI})$ concentrations in advecting water.

\subsection{Chromium(III)-Mineral Dissolution Rates and Subsequent Oxidation Kinetics}

We first determined whether diffusive transport between $\mathrm{Cr}(\mathrm{III})$ solids and $\mathrm{Mn}$ oxides or reaction kinetics (i.e., $\mathrm{Cr}$ (III)-mineral dissolution rates together with subsequent oxidation by $\mathrm{Mn}$ oxides) will be rate controlling. To this end, we compared the maximum diffusive flux considered in our model $\left(\mathrm{FeCr}_{2} \mathrm{O}_{4}\right.$ at $\left.\mathrm{pH}=5 ; d_{r x n}=0.1 \mathrm{~nm}\right)$ with an experimentally derived rate of chromite oxidation by Mn oxide [11]. Using a Mn oxide particle size of $1 \mu \mathrm{m}$, the maximum calculated diffusive flux of $0.02 \mathrm{nmol} \mathrm{h}^{-1}$ was several orders of magnitude less than the experimentally observed rate of $11 \mathrm{nmol}$ $\mathrm{h}^{-1}$ [11]. We therefore assumed that our system will be diffusion limited over all solubilities and separation distances studied, even using conservative $\mathrm{Cr}$-mineral dissolution and subsequent $\mathrm{Cr}$ (III) oxidation rates.

\subsection{Variable Effects of Cr(III) Mineral Solubility on $\mathrm{Cr}$ Oxidation}

We explored the potential for $\mathrm{Cr}(\mathrm{VI})$ generation over a range of $\mathrm{Cr}(\mathrm{III})$-bearing minerals including chromium-hydroxide $\left(\mathrm{Cr}(\mathrm{OH})_{3}\right)$, chromium oxide $\left(\mathrm{Cr}_{2} \mathrm{O}_{3}\right)$, and chromite $\left(\mathrm{FeCr}_{2} \mathrm{O}_{4}\right)$ (Table 2).

Aqueous $\mathrm{Cr}(\mathrm{III})$ concentrations, using the solubilities of these three minerals, were calculated for four different $\mathrm{pH}$ values from $\mathrm{pH} 5$ to $\mathrm{pH} 9$ (assuming an $\mathrm{Fe}(\mathrm{II})$ concentration ranging from 0.01 to $100 \mu \mathrm{M}$ depending on $\mathrm{pH}$ ) (Table 3). Chromite had the largest range of solubility over the $\mathrm{pH}$ range investigated, while $\mathrm{Cr}(\mathrm{OH})_{3}$ was slightly more soluble than $\mathrm{Cr}_{2} \mathrm{O}_{3}$ for any given $\mathrm{pH}$ (Table 3). While aqueous $\mathrm{Cr}(\mathrm{III})$ concentrations predicted in equilibrium with $\mathrm{Cr}(\mathrm{OH})_{3}$-minerals remained similar between $\mathrm{pH}$ of 7.6 and $\mathrm{pH}$ 9, aqueous $\mathrm{Cr}$ (III) concentrations predicted from chromite dropped significantly over the same range (Table 3), a trend reflected in the $\mathrm{Cr}(\mathrm{VI})$ concentrations (Figure 2).

Table 3. Total aqueous $\mathrm{Cr}(\mathrm{III})$ concentrations calculated for the $\mathrm{Cr}(\mathrm{III})$-bearing minerals used in this study.

\begin{tabular}{ccccc}
\hline & $\mathbf{p H}$ & $\mathrm{Cr}(\mathbf{O H})_{\mathbf{3}} \mathbf{( a )}$ & $\mathrm{Cr}_{\mathbf{2}} \mathrm{O}_{3}$ & $\mathrm{FeCr}_{\mathbf{2}} \mathbf{O}_{\mathbf{4}}{ }^{*}$ \\
\hline & 5 & -4.15 & -4.33 & -3.21 \\
$\log \left[\mathrm{Cr}(\mathrm{III})_{\mathrm{T}}\right](\mathrm{M})$ & 6 & -5.97 & -6.14 & -5.41 \\
& 7.6 & -6.82 & -6.99 & -7.33 \\
& 9 & -6.84 & -7.01 & -7.80
\end{tabular}

* Calculated for $\left[\mathrm{Fe}^{2+}\right]$ of $100,10,1$, and $0.01 \mu \mathrm{M}$ for $\mathrm{pH} 5,6,7.6$, and 9, respectively; all solubilities were calculated in Minteq v4 using $\log K$ from Table 2. 

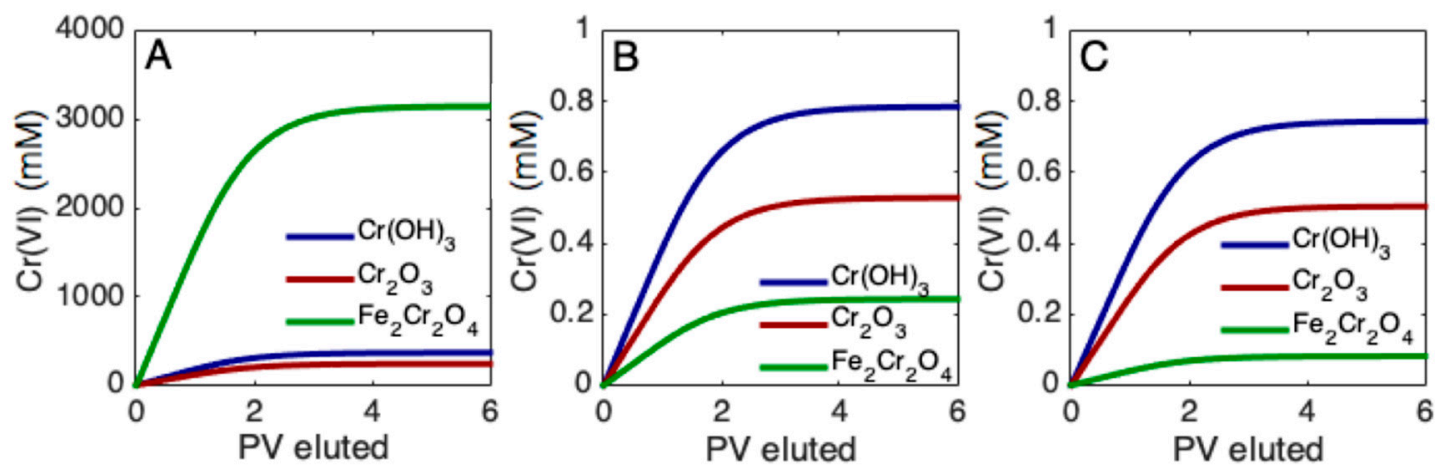

Figure 2. $\mathrm{Cr}(\mathrm{VI})$ concentration in the porewater channel as a function of pore volumes (PV) eluted for $\mathrm{Cr}(\mathrm{OH})_{3}, \mathrm{Cr}_{2} \mathrm{O}_{3}$, and $\mathrm{FeCr}_{2} \mathrm{O}_{4}$ at $\mathrm{pH}$ values of $(\mathbf{A}) \mathrm{pH} 5$ (B) $\mathrm{pH}$ 7.6, and (C) $\mathrm{pH}$ 9. Separation distance $\left(d_{r x n}\right)$ of $\mathrm{Cr}(\mathrm{III})$ mineral and $\mathrm{MnO}_{2}$ was fixed at $1 \mu \mathrm{m}$, diffusion distance $\left(d_{\text {diff }}\right)$ to the advective porewater channel was $1 \mathrm{~mm}$, and porewater velocity $(v)$ was $0.1 \mathrm{~m} \mathrm{~d}^{-1}$ for all cases. Chromite case assumes an $\mathrm{Fe}(\mathrm{II})$ concentration of 100,1 , and $0.01 \mu \mathrm{M}$ for $\mathrm{pH} 5,6,7.6$, and 9, respectively.

To investigate $\mathrm{Cr}(\mathrm{VI})$ production from different $\mathrm{Cr}(\mathrm{III})$-bearing minerals, we used a physical setting where a $\mathrm{Cr}(\mathrm{IIII})$ source was located $1 \mu \mathrm{m}$ from Mn oxides $\left(d_{r x n}=1 \mu \mathrm{m}\right)$ and $1 \mathrm{~mm}$ from advecting porewater $\left(d_{\text {diff }}=1 \mathrm{~mm}\right.$; with a porewater velocity $(v)$ of $\left.0.1 \mathrm{~m} \mathrm{~d}^{-1}\right)$. Although the mass of $\mathrm{Cr}$ minerals within aquifers can impact the extent of $\mathrm{Cr}$ oxidation, differences in solubility between minerals control $\mathrm{Cr}(\mathrm{VI})$ production. As diffusive flux of $\mathrm{Cr}$ (III) scales with solubility, the concentration gradient established by the $\mathrm{Cr}(\mathrm{III})$ solid is the determinant of the reaction rate. For the minerals and $\mathrm{pH}$ values tested, differences in solubility and resulting impacts on groundwater $\mathrm{Cr}(\mathrm{VI})$ concentrations were greatest under acidic conditions. At low $\mathrm{pH}$ values $<6$, chromite yielded $\mathrm{Cr}(\mathrm{VI})$ concentrations several orders of magnitude higher than either $\mathrm{Cr}(\mathrm{OH})_{3}$ or $\mathrm{Cr}_{2} \mathrm{O}_{3}$ (Figure 2A); under more alkaline conditions, however, chromite yielded significantly less $\mathrm{Cr}(\mathrm{VI})$, and the $\mathrm{Cr}(\mathrm{VI})$ levels generated by chromium oxide fell between the two other minerals (Figure 2B,C). In well-mixed batch experiments reacting $\mathrm{Cr}(\mathrm{OH})_{3}$ with $\delta-\mathrm{MnO}_{2}$, Pan et al. [20] found higher $\mathrm{pH}$ values ultimately resulted in greater $\mathrm{Cr}(\mathrm{VI})$ concentrations despite slower oxidation kinetics, attributing it as likely to be the result of Mn dynamics (e.g., increased oxidation of $\mathrm{Mn}(\mathrm{II})$ ). Unlike $\mathrm{Cr}(\mathrm{VI})$ resulting from the chromium (hydr)oxide phases, $\mathrm{Cr}(\mathrm{VI})$ production from chromite at alkaline conditions likely continues to decrease with increasing $\mathrm{pH}$ as a result of $\mathrm{Fe}$ (II) dynamics that influence chromite solubility.

Extensive hydrolytic weathering of ultramafic rocks in tropical climate regimes leads to the formation of deep lateritic soils depleted in $\mathrm{Ca}, \mathrm{Mg}$, and $\mathrm{Si}$, but enriched in $\mathrm{Cr}, \mathrm{Mn}$, and $\mathrm{Fe}$ as well as $\mathrm{Ni}, \mathrm{Co}$, and $\mathrm{V}[10,16,25,26]$. Within ultramafic bedrock, Cr originates in $\mathrm{Cr}(\mathrm{III})$-bearing spinel minerals (e.g., chromite and magnetite), but weathers into secondary minerals (predominantly Cr-hydroxides and Cr-substituted Fe oxides). Studies from a lateritic profile in Niquelândia, Brazil found most of the chromium ( $~ 50-85 \%)$ within well crystalized Fe oxides [27]. The soil $\mathrm{pH}$ in these well-weathered tropical profiles is acidic, allowing the oxidation reaction to proceed to a greater extent before Mn oxide surface passivation by $\mathrm{Cr}(\mathrm{OH})_{3}$ precipitates $[11,26,28]$. The wider range of mineral solubility seen at low $\mathrm{pH}$ values representative of tropical soils suggests that differences in $\mathrm{Cr}(\mathrm{III})$ mineral solubility may control $\mathrm{Cr}(\mathrm{VI})$ concentrations produced from these lateritic profiles spanning Brazil to Madagascar (Table 3; Figure 2) [16,26], depending on the physical constraints (mineral separation distance, distance to advective flow channels, and advective flow rate) of the environment as described below. Contrary to the focus on $\mathrm{Cr}(\mathrm{III})$ weathering products (e.g., $\mathrm{Cr}(\mathrm{OH})_{3}$ ) within well-developed soils, at low $\mathrm{pH}$ values, the higher solubility of chromite suggests that primary minerals could control $\mathrm{Cr}(\mathrm{VI})$ concentrations within these systems. The contribution of chromite to dissolved $\mathrm{Cr}(\mathrm{III})$ concentrations is consistent with chromite grains exhibiting weathering features including irregular morphology and cracks with associated Fe-oxide filled pores [29]. 
Weathering of ultramafic rocks in Mediterranean climates (e.g., California Coast Range and Central Valley) yields soils with modest iron oxide content and alkaline $\mathrm{pH}$. With an increase in $\mathrm{pH}$ above 8 (e.g., California Sacramento Valley) [21,30], secondary weathering products become more soluble than primary minerals like chromite, especially in the presence of high bicarbonate concentrations [31]. If chromite remains a dominate source of $\mathrm{Cr}(\mathrm{III})$, increasing $\mathrm{pH}$ values from $\mathrm{pH} 7.6$ to $\mathrm{pH} 9$ diminishes $\mathrm{Cr}$ (III) concentrations and concomitant $\mathrm{Cr}(\mathrm{VI})$ concentrations by an order of magnitude.

\subsection{Influence of Separation Distance on $\mathrm{Cr}(V I)$}

Our model revealed that the separation distance $\left(d_{r x n}\right)$ between $\mathrm{Cr}(\mathrm{III})$-bearing mineral phases and $\mathrm{Mn}$ oxides (Figure 1) had a prominent control on steady-state $\mathrm{Cr}(\mathrm{VI})$ concentrations within the advecting porewater (Figure 3). $\mathrm{Cr}(\mathrm{VI})$ production from a $\mathrm{Cr}(\mathrm{OH})_{3}$-mineral located $1 \mathrm{~mm}$ from advecting porewater $\left(\mathrm{pH} \mathrm{7.6,v}=0.1 \mathrm{~m} \mathrm{~d}^{-1}\right.$ ) was calculated over a range of separation distances $(0.1 \mathrm{~nm}$ to $1 \mathrm{~cm})$. $\mathrm{Cr}(\mathrm{VI})$ concentrations within the advecting porewater reached a steady-state within a few pore volumes eluted (Figure 3A). Over the range of $\mathrm{Cr}$ (III)-mineral solubilities within this study, the $\mathrm{Cr}(\mathrm{VI})$ steady-state concentrations exhibited a log-log linear dependence on separation distance between Mn and Cr phases (Figure 3B).
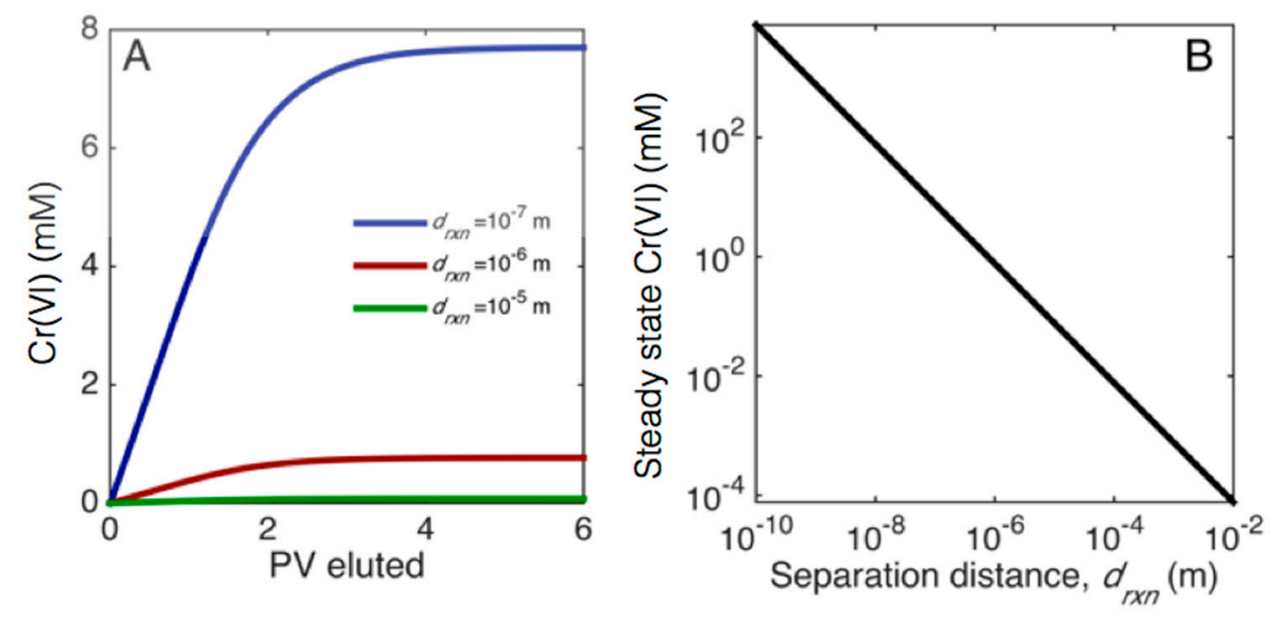

Figure 3. (A) $\mathrm{Cr}(\mathrm{VI})$ concentration in the pore channel as a function of pore volumes (PV) eluted for varying separation distance between $\mathrm{Cr}(\mathrm{OH})_{3}$ and $\mathrm{Mn}(\mathrm{IV})$ phases. Concentrations reached a steady-state within a few pore volumes eluted. (B) Steady-state $\mathrm{Cr}(\mathrm{VI})$ concentration within the pore channel as a function of separation distance between $\mathrm{Cr}(\mathrm{OH})_{3}$ and $\mathrm{Mn}(\mathrm{IV})$ phases $\left(d_{r x n}\right)$ at $\mathrm{pH}$ 7.6. The effective diffusion distance $\left(d_{\text {diff }}\right)$ between the location of $\mathrm{Cr}(\mathrm{VI})$ generation (effectively the Mn-oxide surface) and the advective flow channel was fixed at $1 \mathrm{~mm}$ and velocity was fixed at $0.1 \mathrm{~m} \mathrm{~d}^{-1}$.

As the diffusive flux of $\mathrm{Cr}(\mathrm{III})$ scales with both solubility and $\mathrm{Cr}(\mathrm{III})$ diffusion distance $\left(d_{r x n}\right)$, decreasing the separation distance between $\mathrm{Cr}$ (III)-bearing mineral phases and Mn oxides had the same effect on $\mathrm{Cr}(\mathrm{VI})$ production as increasing the solubility of the $\mathrm{Cr}$ mineral phase. However, while $\mathrm{Cr}(\mathrm{VI})$ concentrations varied $\log -\log$ linearly with both separation distance $\left(d_{r x n}\right)$ and mineral solubility, the range in solubility of $\mathrm{Cr}(\mathrm{III})$ minerals was much smaller than the range of possible separation distances. For example, over the $\mathrm{pH}$ range of 5 to 9 , the maximum difference in solubility between one of the most soluble $\mathrm{Cr}$-minerals, Cr-hydroxide $\left(\mathrm{Cr}(\mathrm{OH})_{3}\right)$, and least soluble minerals, chromite $\left(\mathrm{FeCr}_{2} \mathrm{O}_{4}\right)$, was only over one order of magnitude. In contrast, the range of separation distances between the two reaction phases may range by many orders of magnitude, from nanometers to centimeters $[13,26]$. For aquifers with groundwater $\mathrm{pH}$ values near neutrality to slightly alkaline, the differences in separation distance between $\mathrm{Cr}$ and $\mathrm{Mn}$ phases will overwhelm the influence of mineral solubility. For changes in mineral separation distances just over one order of magnitude, mineral solubility ceases to exert a control on $\mathrm{Cr}(\mathrm{VI})$ concentrations. Given that even an increase in separation distances of a few nanometers may change $\mathrm{Cr}(\mathrm{VI})$ concentrations more than the difference in mineral solubility, any prediction of 
$\mathrm{Cr}(\mathrm{VI})$ concentrations based on solubility would likely be misleading without information of the spatial distribution among the reactive mineral phases.

In poorly weathered mafic and ultramafic rock strata, dissolution of primary minerals releases $\mathrm{Mn}(\mathrm{II})$, allowing Mn oxides to subsequently precipitate along advective flow channels upon contact with oxic groundwater. The Mn(III/IV) minerals coat the rock surfaces [32] and often collocate with $\mathrm{Cr}(\mathrm{III})$-bearing spinel and silicate minerals [30]. For environments where the Mn oxides are distributed proximal to advective flow channels, the separation distance between these Mn phases and $\mathrm{Cr}(\mathrm{III})$-bearing mineral phases would be the best predictor of $\mathrm{Cr}(\mathrm{VI})$ production. Porewater velocity would also determine the magnitude of steady-state $\mathrm{Cr}(\mathrm{VI})$ concentrations.

\subsection{Diffusion Distance Controls Time to a Steady-State}

The diffusion distance through soil micropores within soil aggregates (or peds) or saprolite from $\mathrm{Cr}(\mathrm{VI})$ generation sites to advecting porewater $\left(d_{\text {diff }}\right)$ (Figure 1$)$ has a time-dependent influence on $\mathrm{Cr}(\mathrm{VI})$ concentrations in advecting water; it does not influence the maximum $\mathrm{Cr}(\mathrm{VI})$ concentrations that would result in advecting porewater if the system were to reach a steady-state (Figure 4B). The diffusion distance can, however, significantly impact the time required to reach maximum (steady-state) concentrations. For example, if a $\mathrm{Cr}(\mathrm{OH})_{3}$ particle is $1 \mu \mathrm{m}$ away from a Mn oxide surface $\left(d_{r x n}=1 \mu \mathrm{m}\right)$, and together these minerals are $1 \mathrm{~mm}$ away from an advecting channel $\left(d_{\text {diff }}=1 \mathrm{~mm}\right)$ with a porewater velocity of $0.1 \mathrm{~m} \mathrm{~d}^{-1}, \mathrm{Cr}(\mathrm{VI})$ concentrations will reach a maximum (steady-state) within a day ( $21 \mathrm{~h}$ specifically). Increasing the distance between the oxidation site and advective flow channels by an order of magnitude $\left(d_{\text {diff }}=10 \mathrm{~mm}\right)$ approximately doubles the time to reach a steady state $(39 \mathrm{~h})$. As diffusion distance is further increased to $50 \mathrm{~mm}$, maximum $\mathrm{Cr}(\mathrm{VI})$ concentrations are not reached until after 19 days. If $\mathrm{Cr}(\mathrm{III})$-bearing minerals co-locate with Mn oxides $100 \mathrm{~mm}$ from an advective flow channel, it would take approximately three months to reach a steady-state $(2044 \mathrm{~h})$ (Figure 4A). Typical residence times given the flow velocities used for the study $\left(0.01\right.$ to $\left.1 \mathrm{~m} \mathrm{~d}^{-1}\right)$ range from 18 to 1800 days (assuming vertical thickness of an aquifer $(h=60 \mathrm{~m})$ and porosity $(0.3)$ ).
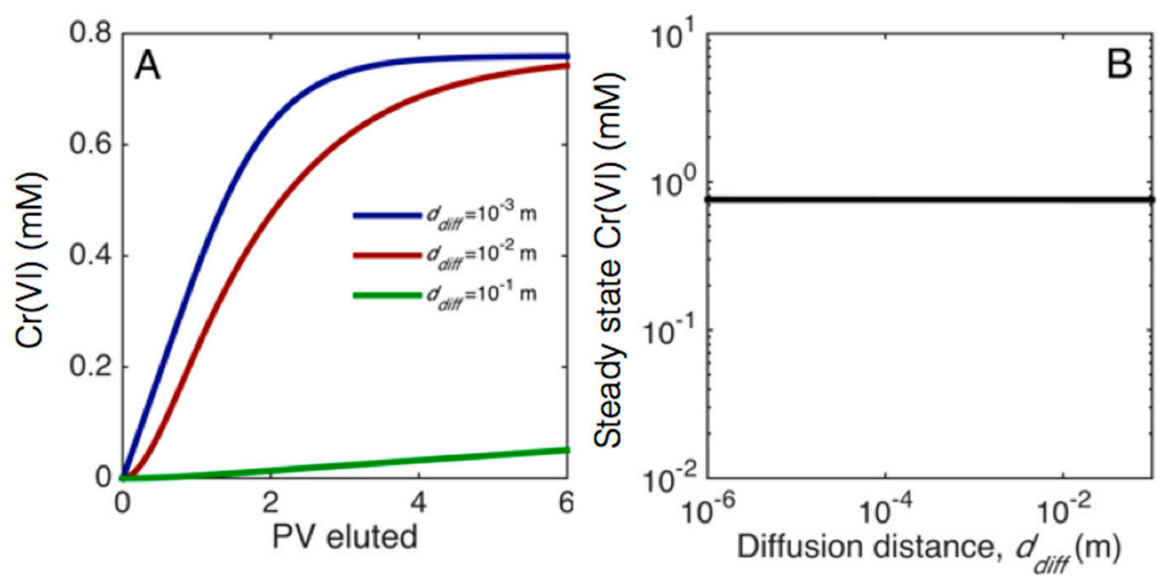

Figure 4. (A) $\mathrm{Cr}(\mathrm{VI})$ concentration in the advective flow channel over the six pore volumes (PV) eluted at varying diffusion distances $\left(d_{\text {diff }}\right)$ (the distance from the point of $\mathrm{Cr}(\mathrm{VI})$ production and the advective flow channel). (B) Steady-state $\mathrm{Cr}(\mathrm{VI})$ concentration as a function of $d_{\text {diff. The separation distance }}$ between $\mathrm{Cr}(\mathrm{OH})_{3}$ and $\mathrm{Mn}(\mathrm{VI})\left(d_{r x n}\right)$ and velocity $(v)$ were fixed at $1 \mu \mathrm{m}$ and $0.1 \mathrm{~m} \mathrm{~d}^{-1}$, respectively (pH = 7.6).

As Mn oxides form at weathering fronts or at anoxic-oxic interfaces, there is an ever-changing landscape of $\mathrm{Cr}$ and $\mathrm{Mn}$ assemblages. Mn oxides often coat advective boundaries, particularly in fracture rock such as saprolite where an influx of oxygenated water oxidizes $\mathrm{Mn}$ (II) catalyzed by mineral surfaces and Mn-oxidizing bacteria [33,34]. As described in Hausladen and Fendorf [35], studies conducted with synthetic aggregates show that in oxic waters with an influx of Mn(II), most 
biogenic Mn oxides precipitate within ca. $4.5 \mathrm{~mm}$ of the advective flow channel. In aquifers impacted by groundwater pumping, water level fluctuations can occur on the order of days and weeks and are of large magnitude $(9-25 \mathrm{~m})[30,32,36]$. If $\mathrm{Cr}(\mathrm{VI})$ generation sites are within a few centimeters of advective flow channels, steady-state $\mathrm{Cr}(\mathrm{VI})$ concentrations should be reached within several days (assuming porewater velocity around $0.1 \mathrm{~m} \mathrm{~d}^{-1}$ ); if $\mathrm{Cr}(\mathrm{VI})$ generation sites lie further away from advective flow channels, however, groundwater flow conditions would likely change before steady-state $\mathrm{Cr}(\mathrm{VI})$ concentrations were reached in aquifers with high hydraulic conductivity or in systems impacted by land runoff or groundwater pumping. In these systems, it is unlikely that $\mathrm{Cr}(\mathrm{VI})$ generated more than $50 \mathrm{~mm}$ from advection flow channels will reach steady-state concentrations, thus resulting in suppressed $\mathrm{Cr}(\mathrm{VI})$ exported from these $\mathrm{Cr}$ generation sites within aggregate interiors.

In environments where $\mathrm{Mn}$ oxides are precipitated distal to the advective flow domain, $\mathrm{Cr}(\mathrm{VI})$ concentrations will generally be limited except for low flow velocities. Consistent with our predictions, observations in the Anthemountas Basin of Greece showed that the highest $\mathrm{Cr}(\mathrm{VI})$ groundwater concentrations correlated with regions of low groundwater velocities [32]. Additional studies showed a direct correlation between $\mathrm{Cr}(\mathrm{VI})$ concentrations and the finest grained sections of alluvial deposits [1].

\subsection{Hydrologic Constraints on $\mathrm{Cr}(V I)$ Concentrations}

Porewater velocities varied widely with values ranging as low as $10^{-5}$ to several meters per day and could alter steady-state $\mathrm{Cr}(\mathrm{VI})$ concentrations (Figure 5) [32]. As porewater velocities increase, $\mathrm{Cr}(\mathrm{VI})$ produced within, and diffusing out of, immobile domains will be increasingly diluted by advecting water, decreasing $\mathrm{Cr}(\mathrm{VI})$ groundwater concentrations. For each order of magnitude increase in porewater velocity, $\mathrm{Cr}(\mathrm{VI})$ concentrations decrease an order of magnitude across all separation distances (Figure 5B). However, as higher flow rates have a bigger impact on the diffusive gradient, steady-state values are reached more slowly at these increased porewater velocities. When separation distance between $\mathrm{Cr}(\mathrm{OH})_{3}$ and $\mathrm{Mn}(\mathrm{IV} / \mathrm{III})$ phases $\left(d_{r x n}\right)$ and diffusion distance $\left(d_{\text {diff }}\right)$ were fixed at $1 \mu \mathrm{m}$ and $1 \mathrm{~mm}$, respectively, steady-state $\mathrm{Cr}(\mathrm{VI})$ concentrations in porewater were reached at 20.2, 8.4, and 4.3 pore volumes eluted with a porewater velocity of $0.01,0.1$, and $1 \mathrm{~m} \mathrm{~d}^{-1}$, respectively (Figure 5A).
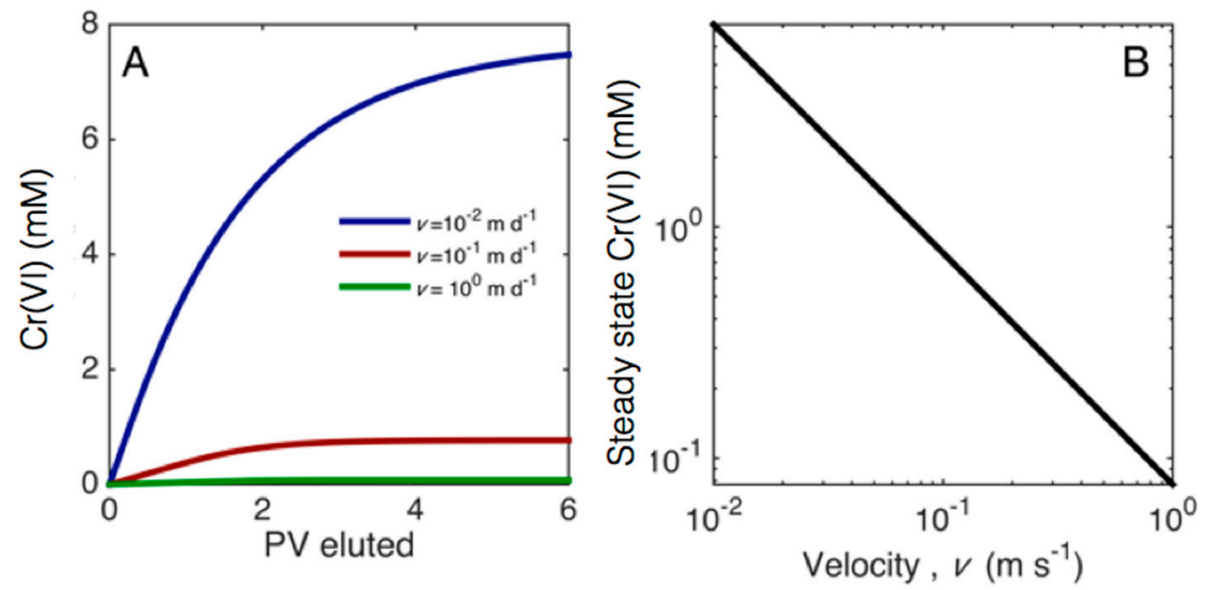

Figure 5. (A) $\mathrm{Cr}(\mathrm{VI})$ concentration in advective flow channel as a function of pore volumes eluted for varying porewater velocities $(v)$. (B) Steady-state $\mathrm{Cr}(\mathrm{VI})$ concentration as a function of $v$. The separation distance between $\mathrm{Cr}(\mathrm{OH})_{3}$ and $\mathrm{Mn}(\mathrm{IV})$ phases $\left(d_{r x n}\right)$ and diffusion distance $\left(d_{\text {diff }}\right)$ were fixed at $1 \mu \mathrm{m}$ and $1 \mathrm{~mm}$, respectively $(\mathrm{pH}=7.6)$.

Together, our analysis helps resolve the seemingly conflicting observations of field observations that show that both higher recharge rates and older groundwater correlate with high $\mathrm{Cr}(\mathrm{VI})$ concentrations $[4,22]$. We suggest that in the recharge zone, increased groundwater velocities are important as they increase the supply of aqueous Mn(II) (from rising groundwater levels) and dissolved oxygen, which can continuously regenerate Mn oxides, especially those in contact with Cr-minerals that 
are the first to undergo reactive dissolution. This minimizes separation distances $\left(d_{r x n}\right)$ and optimizes $\mathrm{Cr}(\mathrm{VI})$ production, in addition to increasing $\mathrm{Cr}(\mathrm{VI})$ flux from the vadose zone, finally concentrating it within aquifers. The accumulation of $\mathrm{Cr}(\mathrm{VI})$ is compounded when it ends up in fine-grained aquifers where slow groundwater flow will allow for maximum $\mathrm{Cr}(\mathrm{VI})$ concentrations, explaining the link between groundwater age and enhanced $\mathrm{Cr}(\mathrm{VI})$ production. In these systems, low porewater velocity results in shallow concentration gradients, allowing for older, slow moving groundwater to yield maximum $\mathrm{Cr}(\mathrm{VI})$ concentrations.

Notably, there are additional environmental processes that were not considered in this study. For example, surface passivation of Mn oxide surfaces has been observed experimentally to limit $\mathrm{Cr}(\mathrm{VI})$ production [37-39], while this model assumes the generation of $\mathrm{Cr}(\mathrm{VI})$ will continue indefinitely. Although the rate and extent of Mn surface passivation will depend on a wide range of physico-chemical parameters (e.g., aqueous $\mathrm{Mn}$ (II) concentrations, $\mathrm{pH}$, carbonate), it is not expected to vary based on the inputs of this model. While the $\mathrm{Cr}(\mathrm{VI})$ generation predicted by this model should be interpreted in light of this limitation, the evaluation of the relative importance of the different reaction parameters would remain unchanged. In addition, the selection of $\mathrm{Cr}$ (III)-bearing mineral phases to explore the variable effects of mineral solubility on $\mathrm{Cr}$ oxidation is limited by available thermodynamic data. Chromite and $\mathrm{Cr}(\mathrm{OH})_{3}$, an amorphous phase resulting from the dissolution of a $\mathrm{Cr}(\mathrm{III})$-bearing mineral, likely approximate the range of $\mathrm{Cr}$ (III)-bearing mineral solubilities; however, a $\mathrm{Cr}(\mathrm{III})$-bearing silicate phase such as Cr-bearing serpentine or chlorite would be more environmentally relevant than $\mathrm{Cr}_{2} \mathrm{O}_{3}$ if the appropriate equilibrium constants were available.

While laboratory studies have investigated how differences in mineral solubility control Cr(VI) generation without contact with reactive Mn oxides [19], to our knowledge there have been no experimental studies to investigate the relative impact of diffusion distance and solubility. This is likely to be due to experimental difficulties associated with designing and measuring nano- to microscale systems. We therefore used a modeling approach in this study, however, with advancements in microfluidics, this could be a valuable avenue for future experimental research.

\section{Conclusions}

Independent of chemical processes, the physical structure of soils and sediments constrains the processes governing groundwater $\mathrm{Cr}(\mathrm{VI})$ concentrations (Figure 1). The five process-steps leading to observed $\mathrm{Cr}(\mathrm{VI})$ concentrations can each exert a control on groundwater concentrations, although the diffusion distance of $\mathrm{Cr}(\mathrm{VI})$ from the location of generation to the advecting porewater (step 4) only influences the time to reach maximum steady-state concentrations. Separation distance between the $\mathrm{Cr}$ (III)-bearing mineral and Mn oxide (step 2) together with porewater velocity (and subsequent dilution, step 5) lead to the greatest range in $\mathrm{Cr}(\mathrm{VI})$ concentrations (Figures 3 and 5). At small separation distances between $\mathrm{Cr}$ (III)-bearing minerals and Mn oxides, $\mathrm{Cr}$ (III) dissolution (step 1) has a principal control on $\mathrm{Cr}(\mathrm{VI})$ concentrations in advecting waters. Thus, in poorly weathered mafic and ultramafic rock strata, dissolution of primary minerals such as olivine and pyroxene may release $\mathrm{Mn}(\mathrm{II})$, allowing Mn oxides to subsequently precipitate along advective flow channels upon contact with oxic groundwater [40]. These Mn(III/IV) minerals coat the rock surfaces [32] and often collocate with $\mathrm{Cr}(\mathrm{III})$-bearing spinel and silicate minerals [30]. For environments where the $\mathrm{Mn}$ oxides are distributed proximal to advective flow channels, the separation distance between these Mn phases and $\mathrm{Cr}(\mathrm{III})$-bearing mineral phases would be the best predictor of $\mathrm{Cr}(\mathrm{VI})$ production. Porewater velocity would also determine the magnitude of steady-state $\mathrm{Cr}(\mathrm{VI})$ concentrations.

It is also important to note that similar $\mathrm{Cr}(\mathrm{VI})$ concentrations can be attributed to a wide-range of physicogeochemical conditions. For example, $\mathrm{Cr}(\mathrm{OH})_{3}$ in a sediment at $\mathrm{pH} 9$ (resulting in aqueous $\mathrm{Cr}(\mathrm{III})$ concentrations of $\left.\mathrm{C}_{\mathrm{o}}=10^{-6.84} \mathrm{M}\right)$ residing an average distance $\left(d_{r x n}\right)$ of $1 \mu \mathrm{m}$ from Mn oxide surfaces exhibits the same $\mathrm{Cr}(\mathrm{VI})$ release profile across all diffusion distances (Figure $6 \mathrm{~A}$ ) as a more poorly soluble $\mathrm{FeCr}_{2} \mathrm{O}_{4}$ mineral (corresponding to $\mathrm{C}_{\mathrm{o}}=10^{-7.80} \mathrm{M}$ ) located an order of magnitude closer to Mn oxides (i.e., $0.11 \mu \mathrm{m}$ away; assuming a constant porewater velocity $(v)$ of $0.1 \mathrm{~m} \mathrm{~d}^{-1}$ for 
both minerals) (Figure 6B). As illustrated in Figure 6 (panel C), the lower solubility $\mathrm{FeCr}_{2} \mathrm{O}_{4}$ mineral can reach identical $\mathrm{Cr}(\mathrm{VI})$ steady-state concentrations observed from $\mathrm{Cr}(\mathrm{OH})_{3}$ even at equal separation distances of $0.1 \mu \mathrm{m}$ if porewater velocities are slowed from 0.1 to $0.011 \mathrm{~m} \mathrm{~d}^{-1}$. Indeed, the advective flow rate will always control $\mathrm{Cr}(\mathrm{VI})$ concentrations with the highest concentrations occurring under low porewater velocities. Chromium(VI) release from sites 1 to $10 \mathrm{~mm}$ away from flow channels were nearly identical for all pore volumes eluted, and significant $\mathrm{Cr}(\mathrm{VI})$ release was even seen for $\mathrm{Cr}(\mathrm{VI})$ production sites $10 \mathrm{~cm}$ from advective channels (Figure $6 \mathrm{C}$ ). If a steady-state is reached, the diffusion distance between $\mathrm{Cr}(\mathrm{VI})$ generation sites and advective flow channels $\left(d_{\text {diff }}\right)$ will never affect the steady-state $\mathrm{Cr}(\mathrm{VI})$ concentrations. However, large diffusion distances between generation sites and advective flow channels may effectively suppress $\mathrm{Cr}(\mathrm{VI})$ release in environments with rapidly changing flow regimes.
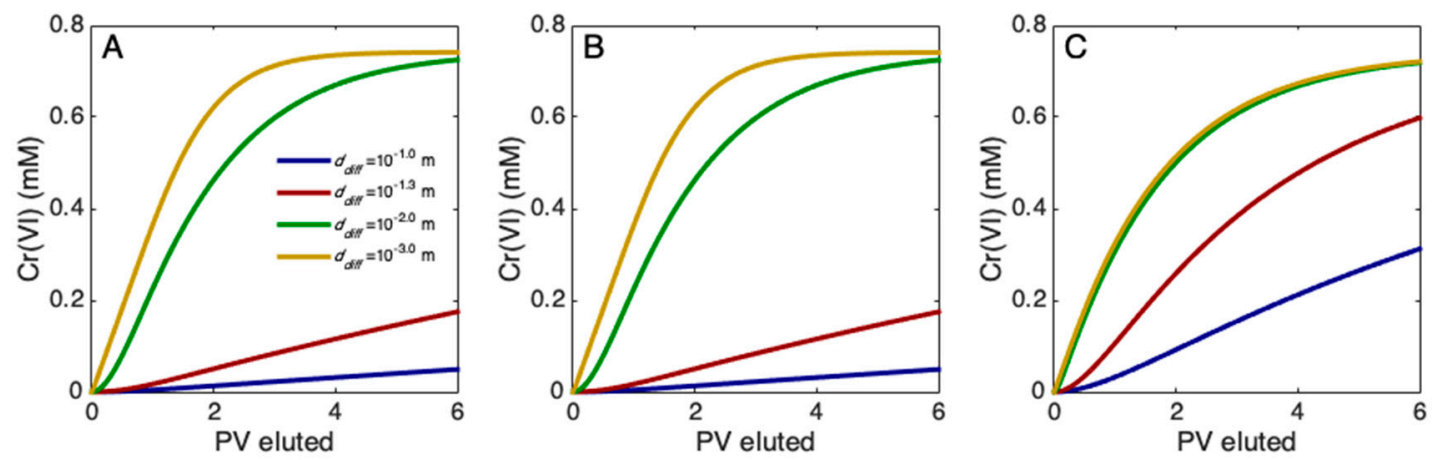

Figure 6. Concentrations in advecting porewater as a function of pore-volume (PV) eluted for multiple diffusion distances $\left(d_{\text {diff }}\right)$ at porewater velocity $(v)$ of $0.1 \mathrm{~m} \mathrm{~d}^{-1}(\mathbf{A}, \mathbf{B})$ and $0.011 \mathrm{~m} \mathrm{~d}^{-1}(\mathbf{C})$. Panel (A) represents $\mathrm{Cr}(\mathrm{OH})_{3}$ at a $\mathrm{pH}$ of 9 (corresponding to $\mathrm{C}_{\mathrm{o}}=10^{-6.84}$ ) and a separation distance $\left(d_{r x n}\right)$ of 1 $\mu \mathrm{m}$ from $\mathrm{MnO}_{2}$. Panel $(\mathbf{B})$ shows $\mathrm{FeCr}_{2} \mathrm{O}_{4}$ at a $\mathrm{pH}$ of 9 (corresponding to $\mathrm{C}_{\mathrm{o}}=10^{-7.80}$ ) and $d_{r x n}=0.11$ $\mu \mathrm{m}$. Panel (C) represents $\mathrm{FeCr}_{2} \mathrm{O}_{4}$ at a $\mathrm{pH}$ of 9 where $d_{r x n}=0.1 \mu \mathrm{m}$ and $v=0.011 \mathrm{~m} \mathrm{~d}^{-1}$.

Our results highlight the importance of physical and hydrologic parameters on endemic $\mathrm{Cr}(\mathrm{VI})$ production within aquifers. The development of $\mathrm{Cr}(\mathrm{III})$ and $\mathrm{Mn}(\mathrm{III} / \mathrm{IV})$ mineral separation distance along with porewater flow velocities predominately control the dissolved concentrations of $\mathrm{Cr}(\mathrm{VI})$ within alkaline groundwater having minimal anoxia. Variation in mineral solubility and surface reactivity have negligible effects on resulting $\mathrm{Cr}(\mathrm{VI})$ levels. For neutral to acidic waters, $\mathrm{Cr}(\mathrm{VI})$ adsorption may have an important, but, in the present study, undetermined, role in resulting groundwater contamination. Anaerobic conditions including microsites will likely further have pronounced influences on $\mathrm{Cr}(\mathrm{VI})$ levels [35], but were not considered in the present simulation. Our results therefore represent likely processes controlling $\mathrm{Cr}(\mathrm{VI})$ concentrations in groundwater for aerobic, alkaline environments. Future work should explore the quantitative impacts of $\mathrm{Cr}(\mathrm{VI})$ adsorption and reduction (resulting from anaerobic zones) on groundwater $\mathrm{Cr}(\mathrm{VI})$ concentrations.

Author Contributions: Conceptualization, D.H. and S.F. (Scott Fendorf); Methodology, S.F. (Sarah Fakhreddine) and D.H.; Validation, D.H. and S.F. (Sarah Fakhreddine); Formal analysis, D.H.; Investigation, D.H. and S.F. (Sarah Fakhreddine); Resources, S.F. (Scott Fendorf); Writing-original draft preparation, D.H.; Writing-review and editing, D.H., S.F. (Sarah Fakhreddine), and S.F. (Scott Fendorf); Visualization, D.H. and S.F. (Sarah Fakhreddine); Supervision, S.F. (Scott Fendorf); Project administration, S.F. (Scott Fendorf); Funding acquisition, S.F. (Scott Fendorf).

Funding: We appreciate the funding support provided by the US Department of Energy (DOE) Office of Science, Office of Biological and Environmental Research (BER) through the Subsurface Biogeochemistry Program (Award Number DE-SC0016544) and the SLAC National Accelerator Laboratory scientific focus area (SFA) (Contract No. DE-AC02-76SF00515).

Acknowledgments: The authors would like to acknowledge Kate Maher and Steve Gorelick for their helpful discussions on model development. 
Conflicts of Interest: The authors declare no conflicts of interest. The funders had no role in the design of the study; in the collection, analyses, or interpretation of data; in the writing of the manuscript, or in the decision to publish the results.

\section{References}

1. Robertson, F. Hexavalent Chromium in the Ground Water in Paradise Valley, Arizona. Gr. Water. 1975, 13, 516-527. [CrossRef]

2. Chung, J.B.; Burau, R.G.; Zasoski, R.J. Chromate Generation by Chromate Depleted Subsurface Materials. Water Air Soil Pollut. 2001, 128, 407-417. [CrossRef]

3. Ball, J.W.; Izbicki, J.A. Occurrence of hexavalent chromium in ground water in the western Mojave Desert, California. Appl. Geochem. 2004, 19, 1123-1135. [CrossRef]

4. Izbicki, J.A.; Ball, J.W.; Bullen, T.D.; Sutley, S.J. Chromium, chromium isotopes and selected trace elements, western Mojave Desert, USA. Appl. Geochem. 2008, 23, 1325-1352. [CrossRef]

5. Morrison, J.M.; Goldhaber, M.B.; Lee, L.; Holloway, J.M.; Wanty, R.B.; Wolf, R.E.; Ranville, J.F. A regional-scale study of chromium and nickel in soils of northern California, USA. Appl. Geochem. 2009, 24, 1500-1511. [CrossRef]

6. Izbicki, J.A.; Bullen, T.D.; Martin, P.; Schroth, B. Delta Chromium-53/52 isotopic composition of native and contaminated groundwater, Mojave Desert, USA. Appl. Geochem. 2012, 27, 841-853. [CrossRef]

7. Izbicki, J.A.; Wright, M.T.; Seymour, W.A.; McCleskey, R.B.; Fram, M.S.; Belitz, K.; Esser, B.K. Cr(VI) occurrence and geochemistry in water from public-supply wells in California. Appl. Geochem. 2015, 63, 203-217. [CrossRef]

8. Hausladen, D.M.; Alexander-Ozinskas, A.; McClain, C.; Fendorf, S. Hexavalent Chromium Sources and Distribution in California Groundwater. Environ. Sci. Technol. 2018, 52, 8242-8251. [CrossRef]

9. Who / Chemical Hazards in Drinking-Water: Chromium. Available online: http://www.who.int/water sanitation_health/water-quality/guidelines/chemicals/chromium/en/ (accessed on 4 November 2019).

10. Oze, C.; Fendorf, S.; Bird, D.K.; Coleman, R.G. Chromium Geochemistry of Serpentine Soils. Int. Geol. Rev. 2004, 46, 97-126. [CrossRef]

11. Oze, C.; Bird, D.K.; Fendorf, S. Genesis of hexavalent chromium from natural sources in soil and groundwater. Proc. Natl. Acad. Sci. USA 2007, 104, 6544-6549. [CrossRef]

12. Nriagu, J.O.; Nieboer, E. Chromium in the Natural and Human Environments; John Wiley \& Sons: Hoboken, NJ, USA, 1988; ISBN 978-0-471-85643-6.

13. Fandeur, D.; Juillot, F.; Morin, G.; Olivi, L.; Cognigni, A.; Webb, S.M.; Ambrosi, J.-P.; Fritsch, E.; Guyot, F.; Brown, J.; et al. XANES Evidence for Oxidation of $\mathrm{Cr}(\mathrm{III})$ to $\mathrm{Cr}(\mathrm{VI})$ by Mn-Oxides in a Lateritic Regolith Developed on Serpentinized Ultramafic Rocks of New Caledonia. Environ. Sci. Technol. 2009, 43, 7384-7390. [CrossRef]

14. Lee, B.D.; Graham, R.C.; Laurent, T.E.; Amrhein, C. Pedogenesis in a wetland meadow and surrounding serpentinitic landslide terrain, northern California, USA. Geoderma 2004, 118, 303-320. [CrossRef]

15. Caillaud, J.; Proust, D.; Philippe, S.; Fontaine, C.; Fialin, M. Trace metals distribution from a serpentinite weathering at the scales of the weathering profile and its related weathering microsystems and clay minerals. Geoderma 2009, 149, 199-208. [CrossRef]

16. Berger, A.; Frei, R. The fate of chromium during tropical weathering: A laterite profile from central madagascar. Geoderma 2014, 213, 521-532. [CrossRef]

17. Becquer, T.; Quantin, C.; Sicot, M.; Boudot, J.P. Chromium availability in ultramafic soils from new caledonia. Sci. Total Environ. 2003, 301, 251-261. [CrossRef]

18. Ure, A.M.; Berrow, M.L. The elemental constituents of soil. Int. Environ. Chem. 1982, 2, 94-204.

19. Pan, C.; Liu, H.; Catalano, J.G.; Qian, A.; Wang, Z.; Giammar, D.E. Rates of Cr(VI) generation from $\mathrm{Cr}_{x} \mathrm{Fe}_{1-x}(\mathrm{OH})_{3}$ solids upon reaction with manganese oxide. Environ. Sci. Technol. 2017, 51, 12416-12423. [CrossRef] 
20. Pan, C.; Liu, H.; Catalano, J.G.; Wang, Z.; Qian, A.; Giammar, D.E. Understanding the roles of dissolution and diffusion in $\mathrm{Cr}(\mathrm{OH}) 3$ oxidation by $-\mathrm{MnO}$. ACS Earth Space Chem. 2019, 3, 357-365. [CrossRef]

21. Mills, C.T.; Morrison, J.M.; Goldhaber, M.B.; Ellefsen, K.J. Chromium(VI) generation in vadose zone soils and alluvial sediments of the southwestern Sacramento valley, California: A potential source of geogenic $\mathrm{Cr}(\mathrm{VI})$ to groundwater. Appl. Geochem. 2011, 26, 1488-1501. [CrossRef]

22. Manning, A.H.; Mills, C.T.; Morrison, J.M.; Ball, L.B. Insights into controls on hexavalent chromium in groundwater provided by environmental tracers, Sacramento Valley, California, USA. Appl. Geochem. 2015, 62, 186-199. [CrossRef]

23. Parkhurst, D.; Appelo, C. User's guide to phreeqc (Version 2): A computer program for speciation, batch-reaction, one-dimensional transport, and inverse geochemical calculations. Water-Resour. Investig. Rep. 1999, 99, 321.

24. Van Genuchten, M.T. General Approach for Modeling Solute Transport in Structured Soils. 1985. Available online: https://inis.iaea.org/search/searchsinglerecord.aspx?recordsFor=SingleRecord\&RN= 19054696 (accessed on 7 July 2019).

25. Schwertmann, U.; Latham, M. Properties of iron oxides in some new caledonian oxisols. Geoderma 1986, 39, 105-123. [CrossRef]

26. Garnier, J.; Quantin, C.; Guimarães, E.M.; Vantelon, D.; Montargès-Pelletier, E.; Becquer, T. Cr(VI) genesis and dynamics in ferralsols developed from ultramafic rocks: The case of Niquelândia, Brazil. Geoderma 2013, 193-194, 256-264. [CrossRef]

27. Garnier, J.; Quantin, C.; Martins, E.S.; Becquer, T. Solid speciation and availability of chromium in ultramafic soils from niquelândia, Brazil. J. Geochem. Explor. 2006, 88, 206-209. [CrossRef]

28. Fendorf, S.E.; Zasoski, R.J. Chromium(III) oxidation by.delta-manganese oxide $\left(\mathrm{MnO}_{2}\right)$. Characterization. Environ. Sci. Technol. 1992, 26, 79-85. [CrossRef]

29. Garnier, J.; Quantin, C.; Guimarães, E.; Becquer, T. Can chromite weathering be a source of Cr in soils. Miner. Mag. 2008, 72, 49-53. [CrossRef]

30. McClain, C.N.; Fendorf, S.; Webb, S.M.; Maher, K. Quantifying Cr(VI) production and export from serpentine soil of the California coast range. Environ. Sci. Technol. 2017, 51, 141-149. [CrossRef]

31. Rai, D.; Moore, D.A.; Hess, N.J.; Rosso, K.M.; Rao, L.; Heald, S.M. Chromium(III) hydroxide solubility in the aqueous $\mathrm{K}+-\mathrm{H}+-\mathrm{OH}--\mathrm{CO} 2-\mathrm{HCO} 3$ - -CO $32--\mathrm{H} 2 \mathrm{O}$ System: A thermodynamic model. J. Solut. Chem. 2007, 36, 1261-1285. [CrossRef]

32. Kazakis, N.; Kantiranis, N.; Voudouris, K.S.; Mitrakas, M.; Kaprara, E.; Pavlou, A. geogenic Cr oxidation on the surface of mafic minerals and the hydrogeological conditions influencing hexavalent chromium concentrations in groundwater. Sci. Total Environ. 2015, 514, 224-238. [CrossRef]

33. Namgung, S.; Kwon, M.J.; Qafoku, N.P.; Lee, G. Cr(OH)3(s) oxidation induced by surface catalyzed Mn(II) oxidation. Environ. Sci. Technol. 2014, 48, 10760-10768. [CrossRef]

34. Tebo, B.M.; Bargar, J.R.; Clement, B.G.; Dick, G.J.; Murray, K.J.; Parker, D.; Verity, R.; Webb, S.M. Biogenic manganese oxides: Properties and mechanisms of formation. Annu. Rev. Earth Planet. Sci. 2004, 32, 287-328. [CrossRef]

35. Hausladen, D.M.; Fendorf, S. Hexavalent chromium generation within naturally structured soils and sediments. Environ. Sci. Technol. 2017, 51, 2058-2067. [CrossRef] [PubMed]

36. Luhdorff and Scalmanini. Groundwater monitoring program, data management system, and update of groundwater conditions in the Yolo County area. Available online: http://www.ycfcwcd.org/pdffiles/reports/ ab\%20303\%20gw\%20final\%20report\%20pdf\%20reduced.pdf (accessed on 3 March 2017).

37. Ying, S.C.; Masue-Slowey, Y.; Kocar, B.D.; Griffis, S.D.; Webb, S.; Marcus, M.A.; Francis, C.A.; Fendorf, s. distributed microbially and chemically-mediated redox processes controlling arsenic dynamics within Mn-/Fe-oxide constructed aggregates. Geochim. Cosmochim. Acta 2013, 104, 29-41. [CrossRef]

38. Tang, Y.; Zeiner, C.A.; Santelli, C.M.; Hansel, C.M. Fungal oxidative dissolution of the Mn(II)-bearing mineral rhodochrosite and the role of metabolites in manganese oxide formation: Dissolution and oxidation of rhodochrosite by fungi. Environ. Microbiol. 2013, 15, 1063-1077. [CrossRef] 
39. Fendorf, S.E.; Fendorf, M.; Sparks, D.L.; Gronsky, R. Inhibitory mechanisms of Cr(lll) oxidation by $\delta-\mathrm{MnO}_{2}$. J. Colloid. Interface Sci. 1992, 153, 37-54. [CrossRef]

40. Cloutis, E.A. Manganese-rich olivines: Identification from spectral reflectance properties. J. Geophys. Res. Planets 1997, 102, 25575-25580. [CrossRef] 